Article

\title{
Revisiting Susan Moller Okin's Justice, Gender, and the Family (1989): Intersectionality, Social Ethos, and Critical Praxis of Gender Justice
}

John Raymond B. Jison

\begin{abstract}
In her influential work Justice, Gender, and the Family (1989), the late feminist and political philosopher Susan Moller Okin writes that "a just future would be one without gender." She argues that the society's veering away from gender renders the family a practical avenue where a sense of egalitarian-humanist justice can be developed. This article revisits her work and appraises the viability of her thesis in the context of women's diverse experiences in underserved societies. By employing the concept of intersectionality, the article reflects on how Okin's argument could be rethought to account for the substantively layered and distinct experiences of women in marginalized communities, and how achieving gender justice should go beyond dismantling gender roles within the family. This can be done by fostering an ethos of gender justice that guides members of the society into thinking about the intersections, complexities, and dynamic processes of individual experiences, and adopting a critical gender praxis to apply meaningful ideas for the creation of viable and holistic strategies in fully addressing gender inequalities.
\end{abstract}

Keywords: critical gender praxis, ethos of gender justice, intersectionality, justice, Okin

Tncidence of gender inequality not just in the economic sphere but also socio-political is well-documented in empirical studies. ${ }^{1}$ The United

${ }^{1}$ See Gunn Elisabeth Birkelund and Arne Mastekaasa, "Restructuring Gender Relations: Women's Labour Market Participation and Earnings Inequality among Households," in Gender Inequalities in the 21st Century: New Barriers and Continuing Constraints, ed. by Jacqueline Scott, Rosemary Crompton, and Clare Lyonette, 242-254 (UK: Edward Elgar Publishing, 2010); Man Yee Kan and Jonathan Gershuny, "Gender Segregation and Bargaining in Domestic Labour: Evidence from Longitudinal Time-use Data," in Gender Inequalities in the 21st Century: New

(C) 2021 John Raymond B. Jison

https://www.kritike.org/journal/issue 29/jison december2021.pdf

ISSN 1908-7330

(cc) BY-NC-ND 


\section{REVISITING}

Nations Development Programme's Human Development Report Office, in its annual Gender Inequality Index, report finds that gender inequality remains stark in most countries in Africa, South America and Asia, posing a barrier to human development. ${ }^{2}$ Inequalities between men and women cut across socio-economic cleavages and remain to be a definitive feature of modern society. Despite the significant strides achieved in affirming sexual and gender equalities, women are still at the receiving end of various types of discrimination and disadvantage.

Susan Moller Okin's Justice, Gender, and the Family (1989) introduces a theory of justice focusing on the family and how the society's veering away from gender can transform the family into an avenue where an egalitarianhumanist gender justice can be developed. Her thesis rests on three main claims: (1) egalitarian humanist justice; (2) injustice of gender; and (3) family as the linchpin of gender. ${ }^{3}$ Okin begins by stating that the family is the primary locus of gender inequality in society. She comments that liberal and libertarian theories, while recognizing the existence of a gendered family, argue that the family is not covered by principles of justice because it is within the ambit of the private sphere. As compared to the public sphere dominated by male interests, the private or domestic sphere is where "men's and women's interests are assumed to be complementary and harmonious, and so not regulated by principles of justice." 4 It appears that the discourse on gender equality, she observes, only emphasizes relations outside and not within the family.

The traditional, gender-structured family life puts women into blatant disadvantage. Domestic duties such as housekeeping and childrearing are traditionally ascribed to women and, therefore, become a site of injustice. Women are expected to be the primary parent and assume all the responsibilities involved in raising children. Injustice occurs when it limits

Barriers and Continuing Constraints, ed. by Jacqueline Scott, Rosemary Crompton, and Clare Lyonette, 153-173 (UK: Edward Elgar Publishing, 2010); Anja-Kristin Abendroth, Silvia Melzer, Alexandra Kalev, and Donald Tomaskovic-Devey, "Women at Work: Women's Access to Power and the Gender Earnings Gap," in ILR Review, 70 (2017); Francisco Perales, Janeen Baxter, and Tsui-o Tai, "Gender, Justice and Work: A Distributive Approach to Perceptions of Housework Fairness," Social Science Research, 51 (2015).

${ }^{2}$ Human Development Report Office, “Gender Inequality Index (GII)," in United Nations Development Program Human Development Reports, <http://hdr.undp.org/en/content/genderinequality-index-gii $>$. 22 (1992).

${ }^{3}$ Joshua Cohen, "Okin on Justice, Gender, and Family," in Canadian Journal of Philosophy,

${ }^{4}$ Will Kymlicka, "Rethinking the Family," in Philosophy and Public Affairs, 20 (1991). As Kymlicka explains, the liberal theory has been characterized by a profound division between the public sphere and the private sphere. There is an assumption that in a highly patriarchal society, only men have the capability to act within the public sphere while women are not expected to contribute to public life.

(C) 2021 John Raymond B. Jison

https://www.kritike.org/journal/issue 29/jison december2021.pdf

ISSN 1908-7330

(cc) BY-NC-ND 
their participation and contribution in public spheres such as economy and politics, and when it widens the income gap between men and women since parenting and child-rearing are traditionally unpaid roles. Thus, the disappearance of gender roles or its prevalence in every aspect of social life enables provision of opportunities and benefits, material or otherwise, that have long been denied to women. Humanist justice that espouses egalitarianism should adhere to principles and practices that aim for the minimization of gender. ${ }^{5}$ This type of justice should not sustain let alone reinforce gender inequalities. Egalitarian humanist justice condemns the feminization of domestic labor and calls for equal sharing of domestic duties between the husband and wife. Okin envisions a society where there is "equal sharing by men and women of paid and unpaid work, of productive and reproductive work." 6 It is a society where gender roles are nonexistent and where families do not mechanically assign responsibilities in reference to one's gender. It is a condition where the division of domestic labor loses its potential of generating injustice because of the obsolescence of "more or less traditional patterns of role differentiation."7 The institution of a genderless family is crucial in providing just treatment for the disadvantaged, specifically women. As Okin writes:

... I claim that the genderless family... is more just to women; it is more conducive to equal opportunity, both for women and for children of both sexes; and it creates a more favorable environment for the rearing of citizens of a just society. Thus, while protecting those whom gender now makes vulnerable, we must also put our best efforts into promoting the elimination of gender. ${ }^{8}$

The act of moving away from gender requires implementation of public policies that aim for equality between men and women. Policy proposals such as mandatory parental leaves, flexible working hours for parents, equal entitlements for single parents, and gender mainstreaming in school curricula, must be in place to encourage and facilitate shared parenting. She argues that these initiatives will work towards transforming families as schools of justice and eliminating gender bias in the household level and, eventually, the societal level.

This article is, in one way or another, a critique of Okin, albeit it will not revolve around her essentializing definitions of family and marriage, i.e.,

5 Susan Moller Okin, Justice, Gender, and the Family (USA: Basic Books, 1989), 175.

${ }^{6}$ Okin, Justice, Gender, and the Family, 171.

${ }^{7}$ Ibid., 172.

${ }^{8}$ Ibid., $183-184$.

(C) 2021 John Raymond B. Jison https://www.kritike.org/journal/issue 29/jison december2021.pdf

ISSN 1908-7330 


\section{REVISITING}

the reliance on traditional family groupings and the assumption that all relationships are heterosexual and monogamous. ${ }^{9}$ Rather, my critical reflections will center on how Okin's arguments resonate with or diverge from the disparate experiences of women in marginalized and impoverished contexts. Dismantling gender roles may be a significant step in developing a genderless society as Okin envisions, but it is highly unlikely that genderrelated injustices will cease even in the long run. In this article, I discuss the concept of intersectionality and underscore the need to analyze the heterogeneous lived experiences of women, especially women at the social margins and in the Global South, with the goal of establishing a more nuanced and holistic approach to address gender inequalities. I conclude by summarizing my main points and offering some ways forward for analysis.

\section{The Intersectionality of Gender (In)justice}

It is not difficult to see how Okin's argument echoes the liberal, Anglo-American feminist thinking that became popular in the 1970s and which points to women's lack of freedom to enter the public sphere or participate in the labor market as the main culprit behind women's systemic disadvantage. ${ }^{10}$ Although women are not legally required to be primary caretakers of their children, the society's inherent expectation is that they do. To meet the burgeoning demands of childrearing along with the host of domestic duties it entails, women choose to work part-time in low-paying jobs or leave the labor market completely. The result is the reinforcement of marriage and the family as "the pivot of a societal system of gender that renders women vulnerable to dependency, exploitation, and abuse" that bolsters another system of unequal distribution of goods, i.e., paid and unpaid work, between husbands and wives. ${ }^{11}$

The advent of neoliberal globalization has brought about immense changes not just in global supply chains but also in the structures and relationships that govern individual behavior. More and more women can be seen joining the labor market and contributing to public life. However, women continue to experience discrimination and sexism. In the United States, it is historically documented that Black women have had paid work and been able to break through the US public life but instead of being a "route to empowerment," their employment became a site of oppression,

\footnotetext{
${ }^{9}$ This can be a subject of another paper.

${ }^{10}$ Wendy Sigle-Rushton, “Intersectionality," in Gender: The Key Guides, ed. by Mary Evans and Carolyn Williams (UK: Routledge, 2013).

${ }^{11}$ Okin, Justice, Gender, and the Family, 136.

(C) 2021 John Raymond B. Jison

https://www.kritike.org/journal/issue 29/jison december2021.pdf

ISSN 1908-7330
}

(c) $)$ BY-NC-ND 
legitimizing the practice of paying meager wages in exchange of hard work. ${ }^{12}$ In the Philippines, female workers still face discrimination on basic access to labor benefits, credits, and opportunities despite the increase in the labor force participation rate among women. ${ }^{13}$ The question is, why do some women continue to experience discrimination despite having been granted more economic freedom?

As an analytical tool "for studying, understanding and responding to the ways in which gender intersects with other identities and how these intersections contribute to unique experiences of oppression and privilege," intersectionality articulates the disparate experiences of oppression experienced by women especially in impoverished societies and underserved groups. ${ }^{14}$ As a concept, it captures the "different dimensions of social life (hierarchies, axes of differentiation, axes of oppression, social structures, normativities) are intersecting, mutually modifying and inseparable"15 and references the "critical insight that race, class, gender, sexuality, ethnicity, nation, ability, and age operate not as unitary, mutually exclusive entities, but as reciprocally constructing phenomena that in turn shape complex social inequalities."16 Kimberlé Crenshaw, a critical race theorist, coined the term intersectionality in her seminal work examining the incapability of the extant antidiscrimination legislation in capturing racism and sexism experienced by

12 Patricia Hill Collins, Black Feminist Thought: Knowledge, Consciousness, and the Politics of Empowerment (New York, USA; London, UK: Routledge, 2000). As Collins explains, “Two major changes affect U.S. Black women's paid labor. The first is Black women's movement from domestic service to industrial and clerical work. The second is Black women's integration into the international division of labor in low-paid service work, which does not provide sufficient income to support a family. When combined, these two factors segment Black working-class women into two subgroups. African-American women holding good jobs in industry and the government sector constitute the core of the Black working class." Collins, Black Feminist Thought, 60.

${ }^{13}$ In particular, the preliminary results of the Labor Force Participation Survey in October 2013 demonstrated a $0.1 \%$ labor force participation rate among women at $49.8 \%$. See International Labor Organization, "Gender Equality in the Philippines," in ILO.org, <https://www.ilo.org/wcmsp5/groups/public/---asia/---ro-bangkok/---ilo-manila/documents/ publication/wcms_173283.pdf>.

${ }^{14}$ Association for Women's Rights in Development (AWID), “Intersectionality: A Tool for Economic and Gender Justice," in Women's Rights and Economic Change, 9 (2004). In other instances, intersectionality is viewed as a "heuristic device" (Henry), a "research paradigm" (Grabe), a "knowledge project" (Collins), and a strand in feminist theorizing, among others. See: Marsha Henry, "On the Necessity of Critical Race Feminism for Women, Peace, and Security," in Critical Studies on Security, 9 (2021); Shelly Grabe, "Research Methods in the Study of Intersectionality in Psychology: Examples Informed by a Decade of Collaborative Work with Majority World Women's Grassroots Activism," in Frontiers in Psychology, 11 (2014); Patricia Hill Collins, "Intersectionality's Definitional Dilemmas," in Annual Review of Sociology, 41 (2015).

${ }^{15}$ Wendy Sigle-Rushton, "Intersectionality," 3.

${ }^{16}$ Patricia Hill Collins, "Intersectionality's Definitional Dilemmas," in Annual Review of Sociology, 41 (2015).

(C) 2021 John Raymond B. Jison https://www.kritike.org/journal/issue 29/jison december2021.pdf ISSN 1908-7330 


\section{REVISITING}

Black women in the United States. ${ }^{17}$ It emerged as a nascent approach to account for the wide-ranging experiences that women of color face in the United States. Feminist scholars from the Global South soon began to employ intersectional analysis to unpack the various forms of discrimination experienced by women in their respective regions, resulting in the development of critical race feminism as a theoretical tool to demarginalize women of color from women studies scholarship. ${ }^{18}$ They argue that the disparate experiences of women needs to be assessed to understand the intricate complexities of gender oppression, and at the same time "expose the unique and varied experiences of women of color as distinct from white women or men of color."19 The realities women face in other contexts distinct from the realities of white-middle class-heterosexual women highlighted the need to forward a more pluralistic and inclusive understanding of women oppression in lieu of the "essential female" voice.

Studies on intersectionality recognize the social fact that (1) people are occupying multiple and layered identities that are (re)produced by the existing social relations and dominant power structures of the time and (2) people can belong to more than one community simultaneously and consequently experience oppression all at the same time.20 To illustrate this point, Martha Nussbaum recounts a Supreme Court case in India where an elderly Muslim woman, after having been divorced by his husband, sued for regular maintenance payments, a right that is accorded to her by the Indian civil law:

In Madya Pradesh in 1978, an elderly Muslim woman named Shah Bano was thrown out of her home by her husband, a prosperous lawyer, after forty years of marriage. (The occasion seems to have been a quarrel over inheritance between the children of Shah Bano and the children of the husband's other wife.) As required by Islamic personal law, he returned to her the mehr, or

17 Kimberlé Crenshaw, "Demarginalizing the Intersection of Race and Sex: A Black Feminist Critique of Antidiscrimination Doctrine, Feminist Theory, and Antiracist Politics," in University of Chicago Legal Forum, 1989 (1989). See also Elizabeth R. Cole, "Intersectionality and Research in Psychology," in American Psychologist, 64 (2009).

${ }^{18}$ Adrien Wing, "Critical Race Feminism," in Theories of Race and Ethnicity Contemporary Debates and Perspectives, ed. by Karim Murji and John Solomos, 162-179 (UK: Cambridge University Press, 2014).

19 Ibid., 165.

${ }^{20}$ A pertinent concept is multiple/multiplicative consciousness, a concept introduced by critical race feminists to analyze intersections in the identities of women of color such as race, gender, age, religion, and other identifying characteristics. See Mari Katsuda, "When the First Quail Calls: Multiple Consciousness as Jurisprudential Method," in Women's Rights Law Reporter, 11 (1989).

(c) 2021 John Raymond B. Jison

https://www.kritike.org/journal/issue 29/jison december2021.pdf

ISSN 1908-7330

(cc) BY-NC-ND 
marriage settlement, that she had originally brought into the marriage-Rs. 3,000 (less than $\$ 100$ by today's exchange rates. Like many Muslim women facing divorce without sufficient maintenance, she sued for regular maintenance payments under Section 125 of the uniform Criminal Procedure Code, which forbids a man "of adequate means" to permit various relatives including (by special amendment in 1973) an ex-wife, to remain in a state of destitution and vagrancy. ${ }^{21}$

Shah Bano is not just a woman who is part of a singular, universal, and homogenous class of women in the world. The social circumstances that women face in the other side of the globe may not be the same for her. The issue of intersectionality becomes relevant as even in the disappearance of gender (or gender roles at the least), injustice against women can persist because they manifest in other forms. ${ }^{22}$ The intersectionality of gender injustice enables us to understand that certain identities or categorizations, religion being one, bring about prejudice against women. In nations where religion wields inordinate power over people's lives, denial of certain liberties can be detrimental to personal development and religious institutions may be deemed unsupportive of certain rights and liberties. Religion has been viewed as a potent social institution that denies certain liberties "to classes of people in accordance with a morally irrelevant characteristic such as race or caste or sex." ${ }^{23}$ Fundamentalist groups may provide rigid restrictions to women on virtually every aspect of their lives, from what to wear, how to talk to and treat men, how to behave as a woman, and so on. Indeed, it is futile to discuss equal sharing of work and pay between husband and wife, let alone parental privileges at work, if women are unable to work because of lack of access to basic social services such as education and health, or because of their deep integration into a cultural or religious group that structurally bars them from doing so.

While there are forms of injustice that are entrenched in matters of gender, $^{24}$ to address gender oppression devoid of these identities is

21 Martha Nussbaum, Women and Human Development: The Capabilities Approach (Cambridge, UK: Cambridge University Press, 2000), 172.

${ }^{22}$ Marcia Lind, "Justice, Gender, and the Family by Susan Okin," in Hypatia, 18 (1993).

${ }^{23}$ Nussbaum, Women and Human Development, 168.

24 "Committee on the Elimination of Racial Discrimination, General Recommendation XXV Gender Related Dimensions of Racial Discrimination (2000)," in International Human Rights Reports, 8 (2001), 309. These include but are not limited to the following: "sexual violence committed against women members of particular racial or ethnic groups in detention or during armed conflict; the coerced sterilization of indigenous women; abuse of women workers in the informal sector or domestic workers employed abroad by their employers."

(C) 2021 John Raymond B. Jison https://www.kritike.org/journal/issue 29/jison december2021.pdf

ISSN 1908-7330 


\section{REVISITING}

inadequate because these identities intersect with each other. For instance, the United International Human Rights Reports, in particular the report by the Committee on the Elimination of Racial Discrimination, has recognized that racial discrimination has gender-related dimensions. ${ }^{25}$ The same goes with the issue of vulnerability. The structures and social relations at play where people derive their multiple identities from make vulnerability a relative position. In a hetero-patriarchal society, women (as compared to men) are vulnerable and elderly women who are poor and part of an indigenous group more so. The level of vulnerability becomes more severe and deeper among women who are old, poor, with disability, and are members of religious minorities. These identities as not separate or distinct from each other but rather constitute an individual.

\section{Ethos of Gender Justice and Critical Gender Praxis}

While a humanist-egalitarian type of justice in the family, as Okin correctly points out, should involve protecting the vulnerable, i.e., women and children, achieving gender justice should be more than dismantling gender roles and liberalizing the family. Gender and all pertinent issues have to be situated "in the context of power relations embedded in social identities," 26 especially if gender is to be understood as the "structure of social relations that centers on the reproductive arena, and the set of practices (governed by this structure) that bring reproductive distinctions between bodies into social processes." 27 The substantively diverse and distinct experiences of women across regions and contexts lend importance to a more inclusive approach in combatting gender-related injustices, both in principle and practice. By principle I mean the ideas, values, and attitudes that need to be produced or reproduced to guide individual and collective behavior towards gender justice. By practice I mean the public policies, programs, pedagogy, research methodologies, and other relevant applications that can be implemented towards the attainment of gender justice. To expound on both, I am guided by the concepts of social ethos of justice and critical gender praxis.

25 "Committee on the Elimination of Racial Discrimination," 309. The first section of the report states that "racial discrimination does not always affect women and men equally or in the same way. There are circumstances in which racial discrimination only or primarily affects women, or affects women in a different way, or to a different degree than men. Such racial discrimination will often escape detection if there is no explicit recognition or acknowledgement of the different life experiences of women and men, in areas of both public and private life."

${ }^{26}$ Stephanie Shields, "Gender: An Intersectionality Perspective," in Sex Roles, 59 (2008).

${ }^{27}$ Raewyn Connell, Gender (Cambridge, UK: Polity Press, 2002), 10.

(c) 2021 John Raymond B. Jison

https://www.kritike.org/journal/issue 29/jison december2021.pdf

ISSN 1908-7330

(cc) BY-NC-ND 


\section{Ethos of (Gender) Justice}

Political theorist Gerard Cohen argues that "a society that is just within the terms of the difference principle, so we may conclude, requires not simply just coercive rules, but also an ethos of justice that informs individual choices." 28 In other words, when there is a social ethos that encourages everyone to pursue egalitarian values and internalize these norms, justice would be potentially obtained as compared to a society where people are motivated by egoistic interests and act within the legal limits. When agents act naturally in accordance with their self-interest, maximizing their own utility to that end, an ethos of justice is imperative to inform individual choices that benefit the general welfare, nudging the society towards justice and fairness.

A society that overcomes gender inequality is one in which everyone in the society is committed to the principles of gender equality and are willing to act accordingly. It is a society in which equal treatment of all is deeply entrenched in the people's minds. Cohen offers an account of how social ethos can propel a sexist society towards equality:

On an extreme view, which I do not accept but need not reject, a typical husband in a thoroughly sexist societyone, that is, in which families in their overwhelming majority display an unjust division of domestic laboris literally incapable of revising his behavior, or capable of revising it only at the cost of cracking up, to nobody's benefit. But even if that is true of typical husbands, we know it to be false of husbands in general. It is a plain empirical fact that some husbands are capable of revising their behavior, since some husbands have done so, in response to feminist criticism. These husbands, we could say, were moral pioneers. They made a path which becomes easier and easier to follow as more and more people follow it, until social pressures are so altered that it becomes harder to stick to sexist ways than to abandon them. That is a central way in which a social ethos changes. ${ }^{29}$

The ethos of gender justice makes possible the crafting of public policies, plans, and programs on gender justice (if they have yet to be created)

${ }^{28}$ Gerard Allan Cohen, If You're an Egalitarian How Come You're So Rich? (Cambridge, Massachusetts: Harvard University Press, 2002), 128.

${ }^{29}$ Cohen, If You're An Egalitarian, 143-144.

(C) 2021 John Raymond B. Jison

https://www.kritike.org/journal/issue 29/jison december2021.pdf

ISSN 1908-7330

(cc) BY-NC-ND 


\section{REVISITING}

and the unwavering commitment to implement public policies, plans, and programs on gender justice (if they had already been created). In the presence of a legal structure that prohibits gender discrimination, the internalization of this social ethos motivates the society to voluntarily abide by these rules even without want of reward or incentive. Indeed, this ethos shall guide people's actions and remind them of their commitment to the principles of justice must be present as well.

\section{Critical Gender Praxis}

Ideational approaches are important in addressing inequalities, but all ideas must take shape in the form of laws and programs, structures, and institutions that permeate social life. The notion of critical gender praxis posits that all theories and ideas should transcend into meaningful practices and interactions, in the process demarginalizing and de-essentializing perspectives of women, especially immigrant women and women of color, both in practice and scholarship. It aims to address inequalities reinforced by political intersectionality, i.e., the marginalization of interests of some subgroups by activists, organizations and/or social movements working towards justice for different groups, thereby underpinning another type of oppression, ${ }^{30}$ and "critique social injustices that characterize complex social inequalities, imagine alternatives, and/or propose viable action strategies for change." 31

Critical gender praxis could be applied various forms and practices such as social justice work, community organizing, political activism, engagements with nongovernmental and public interest organizations, coalition building, research ethics and analysis, public policy and law reforms, and even writing op-eds and speeches, among others..$^{32}$ It behooves the society to analyze intersections of identities to understand women experiences be it in the realm of politics, economy, academia, and the private sector. It entails a bottom-up approach to research and planning, and privileges lived experiences of women as the primary source of information for analysis. To elaborate, "specific inquiries need to be made about the experiences of women living at the margins, the poorest of the poor, and women suffering from different types of oppression. We need both personal

${ }^{30}$ Elena B. Stavrevska, “Enter Intersectionality: Towards an Inclusive Survivor-Centred Approach in Responding to Conflict-Related Sexual Violence," in LSE Blogs Women Peace and Security Forum (10 December 2019), <https://blogs.lse.ac.uk/wps/2019/12/10/enter-intersection ality-towards-an-inclusive-survivor-centred-approach-in-responding-to-conflict-related-sexualviolence/>.

${ }^{31}$ Collins, "Intersectionality's Definitional Dilemmas," 17.

${ }^{32}$ Wing, "Critical Race Feminism," 164.

(C) 2021 John Raymond B. Jison

https://www.kritike.org/journal/issue 29/jison december2021.pdf

ISSN 1908-7330

$(\mathrm{Cc})$ BY-NC-ND 
accounts and testimonies, and also data disaggregated according to race, sex, ethnicity, caste, age, citizenship status and other identities. The analysis should aim to reveal how practices and policies shape the lives of those impacted, as compared to the lives of those not subject to similar influences." 33

Adrien Wing provides an example of how critical praxis can be implemented in development interventions that seek to address gender injustices in the context of the Arab Spring that transpired in the early 2010s:

Assisting women during the Arab season will be enhanced if policy makers and non-governmental organizations (NGOs) used CRF [critical race feminism] praxis. For example, crafting relevant programs will require not lumping women in with men in certain contexts. It will mandate getting an assessment of female needs directly from women themselves or their NGOs and not letting men talk for them. For example, some may want politicization training to be able to actively participate in the political process. Many will want to understand the constitution making options as each nation engages in that process for the first time in many years. Holding an evening session during dinner time that is open to both genders may result in a dearth of women. ${ }^{34}$

In addressing conflict-related sexual violence, Elena Stavrevska makes a case for a survivor-centered approach that amplifies the voices of survivors to adopt a more nuanced (as opposed to gendered, colonial, racial, and single-category) understanding of the different forms of sexual violence. By ensuring an intersectional approach to understanding what constitutes sexual violence, discourse and policy solutions are broadened, paving the way for more permanent solutions that move beyond tokenism and cooptation. ${ }^{35}$

Critical gender praxis requires regulations, policies, and interventions to be holistic. It goes beyond looking at just one structure and considers the overall context of how gender injustices emerge and are reinforced. By gathering perspectives from the grassroots, the goal is to create a framework that is fundamentally rights-based and can be built upwards to

${ }^{33}$ AWID, "Intersectionality," 5.

${ }^{34}$ Wing, "Critical Race Feminism," 173.

${ }^{35}$ Stavrevska, "Enter Intersectionality."

(C) 2021 John Raymond B. Jison https://www.kritike.org/journal/issue 29/jison december2021.pdf

ISSN 1908-7330 


\section{REVISITING}

account for the differentiated experiences and influences that shape and reshape women's lives. ${ }^{36}$

\section{Conclusion}

In this article, I revisited Susan Moller Okin's work Justice, Gender, and the Family and critically reflected on her work's main thesis. Okin emphasizes how the unequal division of domestic labor between the husband and wife renders the family a site of injustice. By protecting the vulnerable and moving towards a "genderless" future where values and expectations on individuals are neither defined nor dictated by stereotypical gender roles, the society inches closer towards attaining egalitarian-humanist justice that is favorable to all, especially women.

Okin's argument, to a certain extent, remains relevant to the present. However, the recent theoretical developments in feminist and gender studies indicate the need to draw greater attention on issues of inclusion, privilege, and power and how they interconnect with matters of gender. ${ }^{37}$ If the goal is to transform a society into one that does not prejudice individuals and categorizations because of gender, then at the outset there needs to be a recognition that not all women have the same universal experience across contexts; women occupy multiple roles, positions, and identities simultaneously; and the attainment of gender justice requires a more inclusive, holistic, and rights-based approach, which implies that policies and regulations should not focus on gender alone but also account for race, age, socioeconomic class, and other identities.

Western scholars such as Okin are still widely read and discussed in academic circles on the other side of the globe, and rightly so as reading seminal works from influential authors illuminate the historical development of thought and ways of thinking in our respective academic fields. However, what I, as a scholar from the Global South, think and understand needs to be situated in the overarching social and political contexts from which I come. It is for this reason that I draw sheer motivation from the concept of intersectionality to understand (or attempt to understand) how women's experiences of injustices in say, the United States, may be divergent from women's experiences in the Philippines. Drawing from lived and personal

${ }^{36}$ As AWID (2004) suggests: "setting priorities for projects, allocate resources to those who are most marginalized as revealed by analyzing intersecting discriminations. Empowering those who have the least access to rights and resources and focusing on processes that lead to poverty and exclusion (e.g., by providing basic medical services and educational opportunities, protecting their livelihood security, or supplying appropriate agricultural technologies and inputs) may affect the greatest tangible advances in terms of women's rights and gender equality."

${ }^{37}$ Wendy Sigle-Rushton, "Intersectionality," 8.

(C) 2021 John Raymond B. Jison

https://www.kritike.org/journal/issue 29/jison december2021.pdf

ISSN 1908-7330

(cc) BY-NC-ND 
experiences of women from marginal and underserved backgrounds, unfortunately, remains underemphasized both in theory and practice.

If dismantling gender roles within the family structure is not enough, then what is? I put forward a two-pronged approach that touches upon how we think (the ideational aspect) and how we act (the practical aspect). An ethos of gender justice should not just constantly remind us of our commitment to the fundamental values of gender justice but also guide us into thinking about the intersections, complexities, and dynamic processes of individual experiences. Further, a critical gender praxis should frame policies and programs in politics, economy, and other realms of human activity to transform ideas and theories into coherent and holistic strategies for social change.

In relation to Okin's work, some questions that linger in my mind are: Is the "private" home naturally unjust? Is it possible for the family as a structure to become a site of resistance for women rather than a site of injustice? Answering these questions would systematically involve going to the field and knowing the experiences and views of women, all the while remaining grounded on a rights-based approach that refrains from singularizing and essentializing explanations of gender oppression.

Department of Social Sciences, University of the Philippines-Los Baños

\section{References}

"Committee on the Elimination of Racial Discrimination, General Recommendation XXV Gender Related Dimensions of Racial Discrimination (2000)," in International Human Rights Reports, 8 (2001).

Abendroth, Anja-Kristin, Silvia Melzer, Alexandra Kalev, and Donald Tomaskovic-Devey, “Women at Work: Women's Access to Power and the Gender Earnings Gap," in ILR Review, 70 (2017).

Association for Women's Rights in Development, "Intersectionality: A Tool for Economic and Gender Justice," in Women's Rights and Economic Change, 9 (2004).

Birkelund, Gunn Elisabeth and Arne Mastekaasa, "Restructuring Gender Relations: Women's Labour Market Participation and Earnings Inequality among Households," in Gender Inequalities in the 21st Century: New Barriers and Continuing Constraints, ed. by Jacqueline Scott, Rosemary Crompton, and Clare Lyonette, 242-254 (UK: Edward Elgar Publishing, 2010).

Cohen, Gerard Allan, If You're an Egalitarian How Come You're So Rich? (Cambridge, Massachusetts: Harvard University Press, 2002).

(C) 2021 John Raymond B. Jison https://www.kritike.org/journal/issue 29/jison december2021.pdf

ISSN 1908-7330 


\section{REVISITING}

Cohen, Joshua, "Okin on Justice, Gender, and Family," in Canadian Journal of Philosophy, 22 (1992).

Cole, Elizabeth R., "Intersectionality and Research in Psychology," in American Psychologist, 64 (2009).

Collins, Patricia Hill, "Intersectionality's Definitional Dilemmas," in Annual Review of Sociology, 41 (2015).

Collins, Patricia Hill, Black Feminist Thought: Knowledge, Consciousness, and the Politics of Empowerment (New York, USA; London, UK: Routledge, 2000).

Connell, Raewyn, Gender (Cambridge, UK: Polity Press, 2002).

Crenshaw, Kimberlé, "Demarginalizing the Intersection of Race and Sex: A Black Feminist Critique of Antidiscrimination Doctrine, Feminist Theory, and Antiracist Politics," in University of Chicago Legal Forum, 1989 (1989).

Grabe, Shelly, "Research Methods in the Study of Intersectionality in Psychology: Examples Informed by a Decade of Collaborative Work with Majority World Women's Grassroots Activism," in Frontiers in Psychology, 11 (2014).

Henry, Marsha, "On the Necessity of Critical Race Feminism for Women, Peace, and Security," in Critical Studies on Security, 9 (2021).

Human Development Report Office, "Gender Inequality Index (GII)," in United Nations Development Program Human Development Reports, $<$ http://hdr.undp.org/en/content/gender -inequality-index-gii>.

International Labor Organization, "Gender Equality in the Philippines," in ILO.org, <https://www.ilo.org/wcmsp5/groups/public/---asia/---robangkok/---ilo-manila/documents/publication/wcms_173283.pdf>.

Kan, Man Yee and Jonathan Gershuny, "Gender Segregation and Bargaining in Domestic Labour: Evidence from Longitudinal Time-use Data," in Gender Inequalities in the 21st Century: New Barriers and Continuing Constraints, ed. by Jacqueline Scott, Rosemary Crompton, and Clare Lyonette, 153-173 (UK: Edward Elgar Publishing, 2010).

Katsuda, Mari, "When the First Quail Calls: Multiple Consciousness as Jurisprudential Method," in Women's Rights Law Reporter, 11 (1989).

Kymlicka, Will, "Rethinking the Family," in Philosophy and Public Affairs, 20 (1991).

Lind, Marcia, "Justice, Gender, and the Family by Susan Okin," in Hypatia, 18 (1993).

Nussbaum, Martha, Women and Human Development: The Capabilities Approach (Cambridge, UK: Cambridge University Press, 2000).

Okin, Susan Moller, Justice, Gender, and the Family (USA: Basic Books, 1989).

(C) 2021 John Raymond B. Jison

https://www.kritike.org/journal/issue 29/jison december2021.pdf

ISSN 1908-7330

(cc) BY-NC-ND 
Perales, Francisco, Janeen Baxter, and Tsui-o Tai, “Gender, Justice and Work: A Distributive Approach to Perceptions of Housework Fairness," Social Science Research, 51 (2015).

Shields, Stephanie, "Gender: An Intersectionality Perspective," in Sex Roles, 59 (2008).

Sigle-Rushton, Wendy, "Intersectionality," in Gender: The Key Guides, ed. by Mary Evans and Carolyn Williams (UK: Routledge, 2013).

Stavrevska, Elena B., "Enter Intersectionality: Towards an Inclusive SurvivorCentred Approach in Responding to Conflict-Related Sexual Violence," in LSE Blogs Women Peace and Security Forum (10 December 2019), <https://blogs.lse.ac.uk/wps/2019/12/10/enter-intersectionality -towards-an-inclusive-survivor-centred-approach-in-responding-toconflict-related-sexual-violence/>.

Wing, Adrien, "Critical Race Feminism," in Theories of Race and Ethnicity Contemporary Debates and Perspectives, ed. by Karim Murji and John Solomos (UK: Cambridge University Press, 2014). 